\title{
Diethyl Ether Production Process with Various Catalyst Type
}

\author{
Widayat $^{1 *}$, Achmad Roesyadi ${ }^{2}$, Muhammad Rachimoellah ${ }^{2}$ \\ ${ }^{1}$ Dept. of Chemical Engineering \\ Diponegoro University, Jl. Prof. Sudharto, Kampus UNDIP Tembalang, Semarang 50239, Indonesia \\ ${ }^{2}$ Department of Chemical Engineering, Industrial Technlogy Faculty \\ Institute of Technology Sepuluh Nopember Surabaya Indonesia \\ e-mail: yayat_99@yahoo.com
}

\begin{abstract}
Several H-zeolite and HZSM-5 catalysts was preparated and their characters have also been investigated. H-zeolit Catalyst was preparated from Natural Zeolite that obtained from Malang District and Gunung Kidul District. Diethyl ether was produced by Ethanol with concentration of 95\%. This research use fixed bed reactor that 1 gram of catalyst as bed catalyst, atmospheric pressure and temperature $140^{\circ} \mathrm{C}$ as the operating condition. Ethanol vapor from vaporization tank was driven by $200 \mathrm{ml} / \mathrm{min}$ Nitrogen stream. The responds in this research is liquid product concentration; diethyl ether, ethanol, methanol and water concentration. The results showed that the largest ethanol conversion was produced by the use of 56.44\% HZSM-5 and the largest yield of diethyl ether diethyl was produced by the use of alumina and $\mathrm{H}$-zeolite catalyst. The larger ratio between natural zeolite with $\mathrm{HCl}$ solvent will produce the larger surface area of catalyst and ethanol conversion. The largest ethanol conversion was produced at reactan ratio 1:20.
\end{abstract}

[Keywords: catalyst; ethanol conversion; dehydration process; yield of diethyl ether; natural zeolite].

\section{INTRODUCTION}

Diethyl ether is one of the most important commercial ether. In industry, Diethyl ether is often used as a solvent of organic reactions such as oil, fat, latex, micro cellulose, perfume, alkaloid solvent. This ether is also used as a separator of organic compound from its natural material sources. In addition, diethyl ether is identical to anesthesia in medical science $^{[1]}$.

Diethyl ether can be produced using homogenous catalyst (sulfuric acid/Barbet process) and heterogeneous catalyst. The difficulty of Catalyst separation becomes the weakness of Barbet process. Furthermore, the corrosive behavior of Barbet process causes this process becomes costly. The second process, heterogeneous catalyst, uses alumina catalyst. In this process, ethanol conversion per pass and its yield is $60-80$ and $90 \%$ respectively ${ }^{[1]}$. Butt, et al ${ }^{[2]}$ and de Boer, et al ${ }^{[3]}$, studied kinetic reaction of this process.

Evidently, the use of alumina catalyst in ethanol dehydration process produces a low ethanol conversion and diethyl ether yield. Therefore, researchers develop the type of catalyst that can be used for ethanol hydration and dehydration process such as Alumina, $\mathrm{MgO}$, alumina silica and $\mathrm{WO}_{3}$ catalyst ${ }^{[4]}$. In addition, zeolite can also be used for this process. Takahara, et al ${ }^{[5]}$ used H-modernite type of zeolite for ethylene production. In this production process, ethanol was dehydrated to be diethyl ether and subsequently becomes ethylene. The result showed that $\mathrm{H}$-modernite with ratio of $\mathrm{SiO}_{2} / \mathrm{Al}_{2} \mathrm{O}_{3} \quad 90$ is more stable than $\mathrm{H}$-modernite with $\mathrm{SiO}_{2} / \mathrm{Al}_{2} \mathrm{O}_{3} 20^{[5]}$. Haber, et al ${ }^{[6]}$ has a research about ethanol dehydration process with Kalium saline and silver from tungstophosphoric acid (HPW) by varying the type and the number of cation $\mathrm{K}_{\mathrm{x}} \mathrm{H}_{3-\mathrm{x}} \mathrm{PW}_{12} \mathrm{O}_{40}$ and $\mathrm{Ag}_{\mathrm{x}} \mathrm{H}_{3-\mathrm{x}} \mathrm{PW}_{12} \mathrm{O}_{40}$. In his research, value of $\mathrm{x}$ was varied in the range of $0<\mathrm{x}<2$ for $\mathrm{K}_{\mathrm{x}} \mathrm{H}_{3-\mathrm{x}} \mathrm{PW}_{12} \mathrm{O}_{40}$ and $0<\mathrm{x}<3$ for $\mathrm{Ag}_{\mathrm{x}} \mathrm{H}_{3-\mathrm{x}} \mathrm{PW}_{12} \mathrm{O}_{40}$. The result showed that the catalytic activity of the both process was improved. This result shows that catalytic activity has a relation to proton acid and proton that is produced by silver cation. In a high temperature $(\mathrm{T}>573 \mathrm{~K})$, the highest yield of acetaldehyde from dehydrogenation ethanol oxidation is

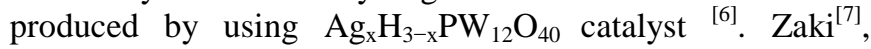
studied about the effect of transition metal from $\mathrm{Fe}_{2} \mathrm{O}_{3}$ and $\mathrm{Mn}_{2} \mathrm{O}_{3}$ in catalytic ethanol dehydration process. The result showed that there was an improvement in ethylene selectivity [7]

Varisli et al ${ }^{[8]}$, also studied diethyl ether and ethylene production process with dehydration ethanol reaction on various catalysts. In this research, TPA (tungstophosphoricacid), STA (silicotungsticacid) and MPA (molydophosphoricacid) catalyst was used. The result showed that the highest Selectivity of ethylene $(>0.75)$ was produced at $250^{\circ} \mathrm{C}$ with TPA catalyst. At temperature $180^{\circ} \mathrm{C}$, the main product was diethyl ether. Furthermore, the presence of water vapor decreased the catalyst activity. Trends of Polyacid catalyst activity can be arranged from the largest value as $\mathrm{STA}>\mathrm{TPA}>\mathrm{MPA}^{[8]}$.

The recent research is objected to investigate the type of catalyst in ethanol dehydration process to produce diethyl ether. The types of catalyst, which are used in this research, are alumina, HZSM-5, and H-zeolit. In addition, H-zeolite is made of natural zeolite from Kabupaten Gunung Kidul district and Malang district.

\section{MATERIALS AND METHODS}

Zeolite is synthesized from natural zeolite, whereas chloride acid is produced from Brataco. $\mathrm{AgNO}_{3}$ is used as indicator of chloride ion washing. Materials to create HZSM-5 catalyst are aquadest, waterglass, alumonium sulphate, sulphate acid, natrium hydroxide and amonium chloride. Materials for diethyl ether production process are tehnical ethanol (95\%) and nitrogen gas. ZSM-5 catalys is produced

E Journal 
based on Latourette, et al method ${ }^{[11]}$. Solution A which contains alumonium sulphate, sulphate acid and water is mixed with solution $\mathrm{B}$ which contains waterglass and aquadest. Solution C contains $\mathrm{NaOH} 40 \%$ which is added to solution A and B. Afterwards, this solution is strirred to make a homogenous solution at PH 9.5. After this step, the solution is placed and stirred in an autoclave with a heating at temperature $150^{\circ} \mathrm{C}$ within 24 hours. The produced crystal is washed, dried and calcinated. In order to get HZSM-5, the ion of the product is exchanged with amonium chloride and continued with the washing, drying and calcinating.

In this experiment, alumina catalyst/alumonium oxyde from a merck which have specification of surface area in the range of $190 \mathrm{~m}^{2} / \mathrm{gram}$ is used. As stated before, H-zeolite is produced from natural zeolite which is obtained from Wonosari district, Gunung Kidul district and Malang district. Characteristic of zeolite is shown in a result of the research of Widayat, et al ${ }^{[12]}$. The catalyst is produced with chemical treatment, washing, drying and calcination process. The chemical treatment is processed in three-neck flask which is equpped with cooler, water heater, and magnetic stirrer. Washing is processed to remove the $\mathrm{Cl}^{-}$ion. Drying is processed with an oven at temperature $110^{\circ} \mathrm{C}$. Calcination is processed with furnace which is equipped with temperatur control. Catalyst product which is produced from natural zeolite of Gunung Kidul district is called $\mathrm{KZ} \mathrm{A}$, whereas the catalyst product from natural zeolite of Malang district is called KZ B. In addition, H-zeolite catalyst is shyntesized by variying the ration og the weight of zeolite and chloride acid solvent.

Catlytic test equipment is shown in figure 1. Fixed bed reactor is placed in a furnace. Feed/ethanol vaporizer tank and nitrogen gas is used as gas booster and inert. The condensorr is used to cendense the is reaction producet. The dimension of the fixed bed reactor is $1 / 2$ inci of diameter and 1 gram of catalyst weight. In order to create catalyst bed, the reactor is eqipped with mesh buffer and glasswool on the both side

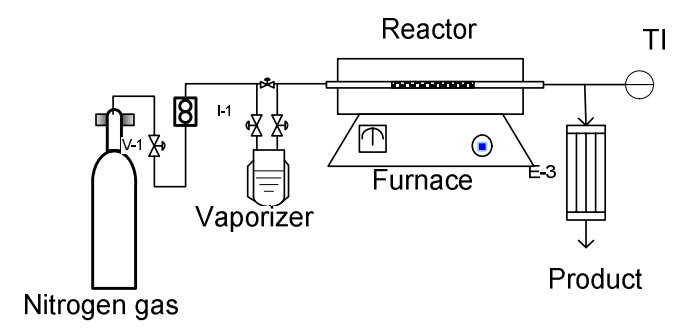

Figure 1. Ethanol dehydration process equipment

Diethyl ether production is processed with 1 gram of KZ A, KZ B, HZSM-5 and alumina catalyst at initial temperature $140^{\circ} \mathrm{C}$, within 15 minutes. Ethanol vapor is boosted with nittrogen gas flow with a flow rate $200 \mathrm{ml} / \mathrm{min}$. During 15 minutes, the product is condensed and analyzed with gas chromatography.

The characteristics is analyzed in intrumentation laboratory of Chemical Engineering Department FTI ITB. Cristalit characteristic with $\mathrm{X}$ ray Difraction (XRD) is analyzed in Research Center ITS. The product is analyzed in chemical analysis laboratory Politeknik Negeri Malang by gas chromatography. The chromatography gas uses TCD detector
(Temperature Conductivity Detector) with helium gas as gas carrier with flow rate $20 \mathrm{ml} / \mathrm{menit}$, temperature $125-250^{\circ} \mathrm{C}$ and detector temperature $275{ }^{\circ} \mathrm{C}$. Components which are analyzed are diethyl ether, ethanol, water and methanol.

\section{RESULTS AND DISCUSSION}

Characteristics test is analyzed with X-ray Diffraction (XRD). Figure 2 shows the analysis result of the difractogram analysis for zeolite catalyst with raw material from Gunung Kidul district (KZ A) and Malang District (KZ B). It can be observed that $\mathrm{KZ}$ A has more peak than $\mathrm{KZ} \mathrm{B}$ at degree of theta 20-30. With a domination of Si composition, Catalyst tends to have a form as Silicate for KZ A and Modernite for $\mathrm{KZ} \mathrm{B}$. Intensity of KZ B catalyst is higher than KZ A catalyst. The diference of peak can also be observed at degree 2 theta 13 and 15 , where the intensity of $\mathrm{KZ} \mathrm{A}$ is higher thatn $\mathrm{KZ} \mathrm{B}$ catalyst.

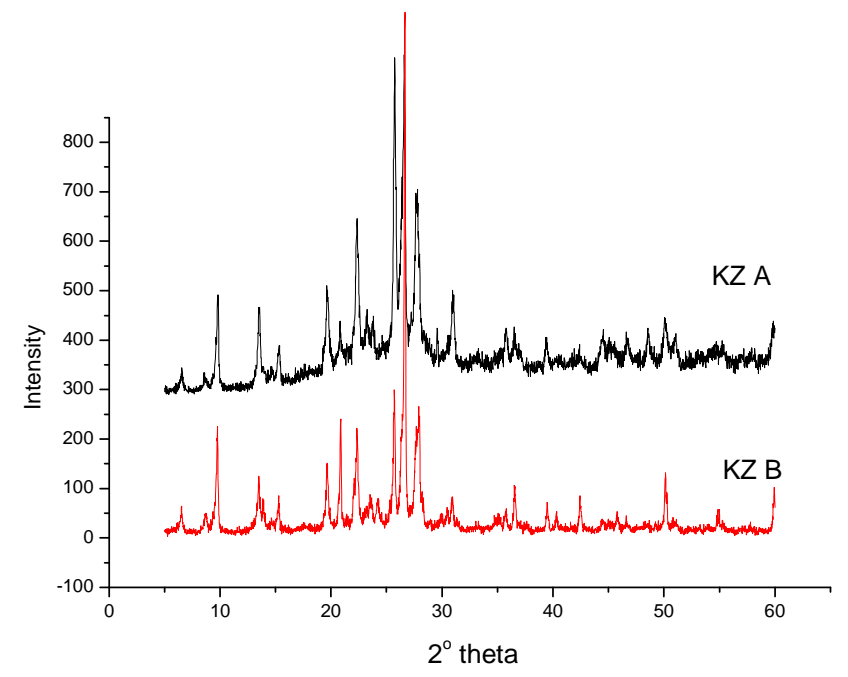

Figure 2. Difractogram of H-Zeolite catalyst product

Cristality analysis result for variation of natural zeolite weight and solvent volume ration is shown in figure 3. Figure 3 shows that the all catalyst product have similar peaks. Most of each point in degree 2 theta have the similar peaks. This result is produced for both calcination or pre-calcination process. In addition, the peak height difference show the difference of concentration.

$\mathrm{XRD}$ analysis result can be seen in figure 4 . this figure shows standart and systetic difractogram HZSM-5 pattern. The specific peak of HZSM-5 is observed at value of $2 \theta$ between $7-9^{0}$ and between $22-25^{\circ}$. Based on the comarison between difractogram pattern of synthetic and standart analysis, it can be concluded that both of analysis give the same result. Therefore it can also be concluded that the product of synthesis is HZSM-5. XRD analysis result from figure 3 have an amorphous form and show an intensity at $2 \theta$ between $22-25^{\circ}$.

The next zeolite catalyst character analysis to investigate the surface area and total pores volume. Measurement of surface area and total pores volume using Quantachrome NOVA 1000 High Speed Gas Sorption Analyser dengan Po = $711,65 \mathrm{mmHg}$ and nitrogen gas as adsorb gas/inert. Analysis result is hown in Table 1. 


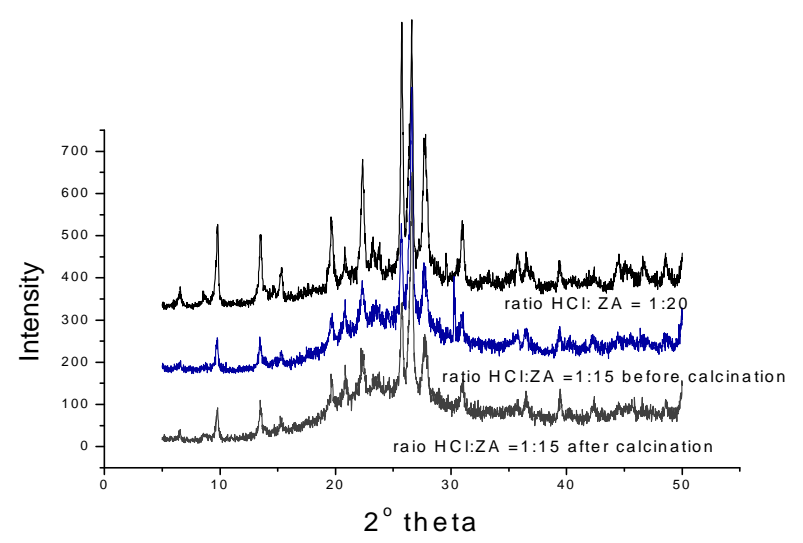

Figure 3. XRD difractogram result of H-Zeolite catalyst: the effect of reactant ratio

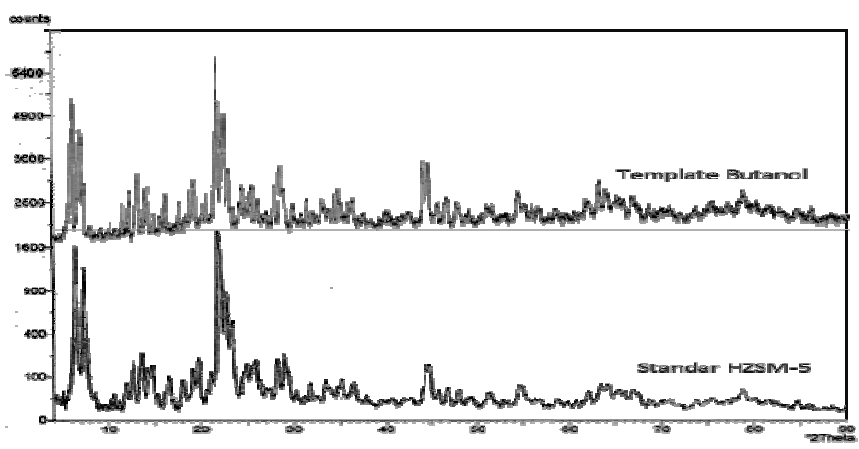

Figure 4. Analysis result of XRD HZSM-5 syntethic and HZSM-5 standart.

Table 1. Analysis results of surface area and total pore volume

\begin{tabular}{llc}
\hline Catalyst type & $\begin{array}{c}\text { Specific surface } \\
\text { area }\left(\mathrm{m}^{2} / \mathrm{g}\right)\end{array}$ & $\begin{array}{c}\text { Pore volume } \\
(\mathrm{cc} / \mathrm{g}) \times 10^{3}\end{array}$ \\
\hline KZ A & 184,5240 & 108,243 \\
KZ B & 130,2086 & 75,272 \\
KZ A: $1 / 10$ & 59,8937 & 35,511 \\
KZ A: $1 / 15$ & 135,7537 & 81,191 \\
KZ A: $1 / 20$ & 172,9295 & 101,763 \\
KZ A: $1 / 30$ & 70,4280 & 40,678 \\
HZSM-5 & 149,918 & - \\
Alumina & 200 & - \\
\hline
\end{tabular}

Table 1 shows that escalation of dealumination time have no significant effect to the surface area and total pores volume. In general, surface area of natural zeolite is around 20 $\mathrm{m}^{2} / \operatorname{gram}^{[12]}$. Dealumination and calcination make some changes to the surface arean and total pores volume. Alumination causes escalation of $\mathrm{Si} / \mathrm{Al}$ ration and aluminasi menyebabkan peningkatan perbandingan $\mathrm{Si} / \mathrm{Al}$ dan dissolving of impurity $\mathrm{CaO}$. The escalation ration of $\mathrm{n} \mathrm{SiO}_{2} / \mathrm{Al}_{2} \mathrm{O}_{3}$ causes a changes of zeolite structure. This changes is caused by Hydrolisis reaction and calcination process. The highest specific surface area and largest total pores volume are produced at dealumination time of 10 hours. Surface area of $\mathrm{KZ} \mathrm{B}$ is smaller that $\mathrm{KZ}$ A catalyst product. In addition, table 1 also shows the escalation of surface area and total pores colume. The highest escalation id produced at ratio of Zeolite and $\mathrm{HCl}$ of $1: 20$.

Test result of Production process shows that the produced products contains methanol, water, diethyl ether and ethanol residue. This is shown in figure 5 and 6 . Figure 5 shows chromatogram result for standart solution where water component is detected at retention time $3.38 \mathrm{~min}$, methanol (RT $5.89 \mathrm{~min}$ ), ethanol (RT 7.18 menit) and diethyl ether (RT 9.86 menit).

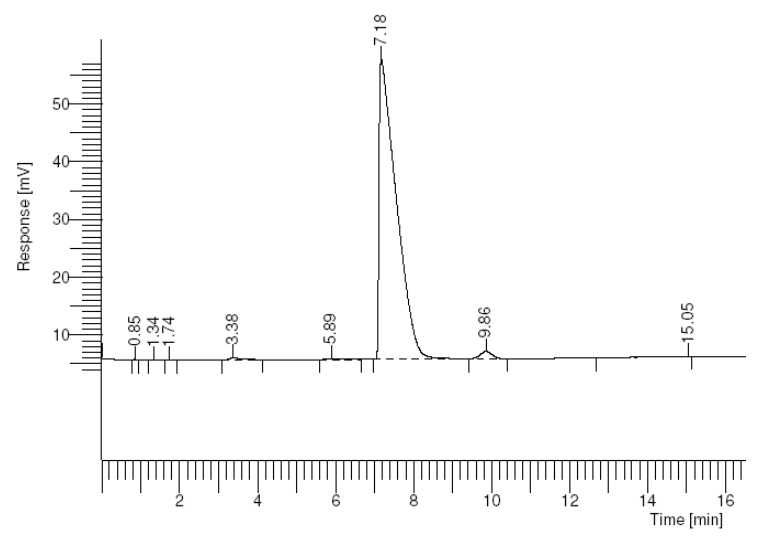

Figure 5. Chromatogram of standart solution

Chromatogram of dehydration process product is shown in figure 6. Figure $6 \mathrm{a}$ is chromatogram of diethyl ether production process result using alumina catalyst, whereas figure 6.b is using $\mathrm{KZ}$ A catalyst, figure 6.c using $\mathrm{KZ} \mathrm{B}$ catalyst and 6.d using HZSM-5 catalyst. Alumina and H-zeolite catalyst (KZ A and KZ B) produces diethyl ether. Alumina catalyst is often used in ethanol dehydration process ${ }^{[2],[3]}$. KZ A catalyst is silicalite, where its mainly component is silica that can be used as catalyst in diethyl ether production process. KZ B catalyst is zeolite with mordenite type that contains silica and aluminum that can be used for ethanol dehydration process. HZSM-5 catalyst does not produce diethyl ether, but produce a lot of water. From the reaction of ethanol conversion reaction, it can be analyzed that ethylene might be produced when HZSM-5 catalyst is used. Therefore, production process with HZSM-5 catalyst does not produce diethyl ether but produce ethylene. This is caused by the addition of water concentration in analysis result of gas chromatography (figure 6.d).

The next catalytic test of ethanol dehydration is data processing to calculate ethanol conversion and diethyl ether yield. The used of equation is as follow.

$$
\begin{aligned}
& x=\frac{F_{A O}-F_{A}}{F_{A O}} \times 100 \% \\
& \text { Yield of DEE }=\frac{\text { Mass of DEE (gram) }}{\left(F_{A O} F_{A}\right)(\text { gram })} \times 100 \%
\end{aligned}
$$

The result of calculation is shown in table 2. Table 2 shows that the largest ethanol conversion for natural zeolite from Gunung Kidul district is produced by KZ A 10 catalyst, whereas the largest ethanol conversion for natural zeolite from Malang district is produced by KZ B 15 catalyst. 


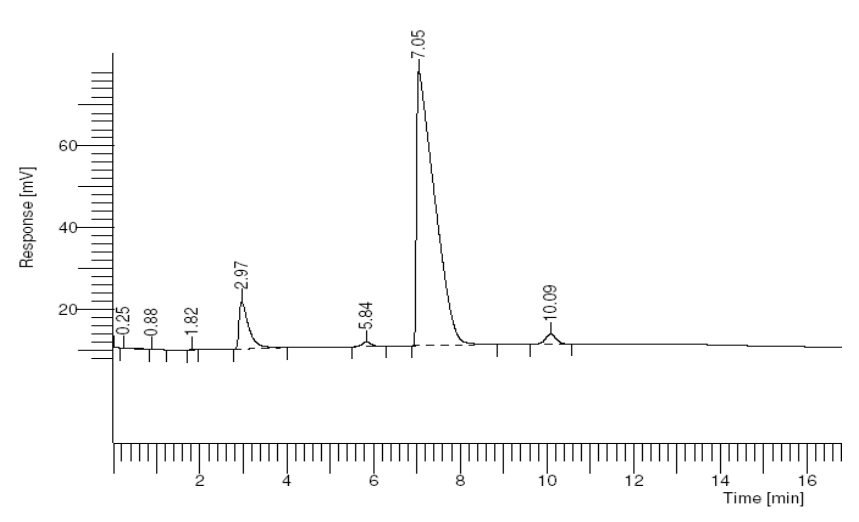

a. alumina catalyst

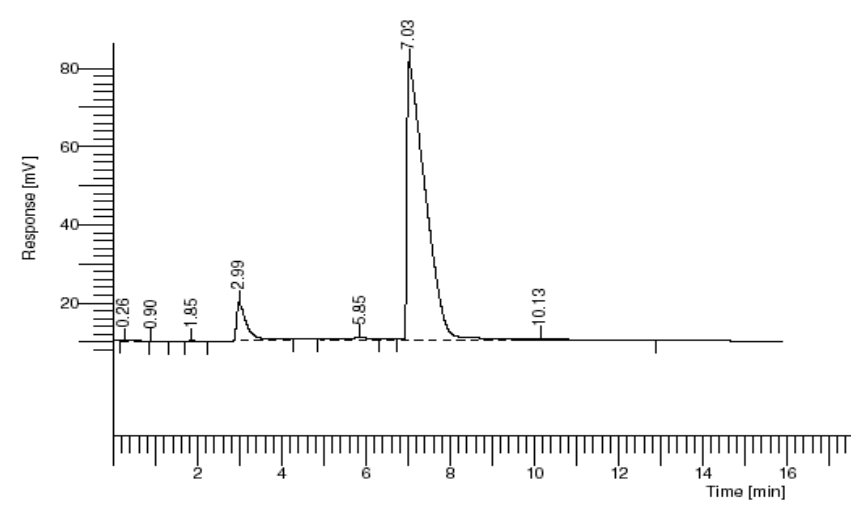

b. KZ A

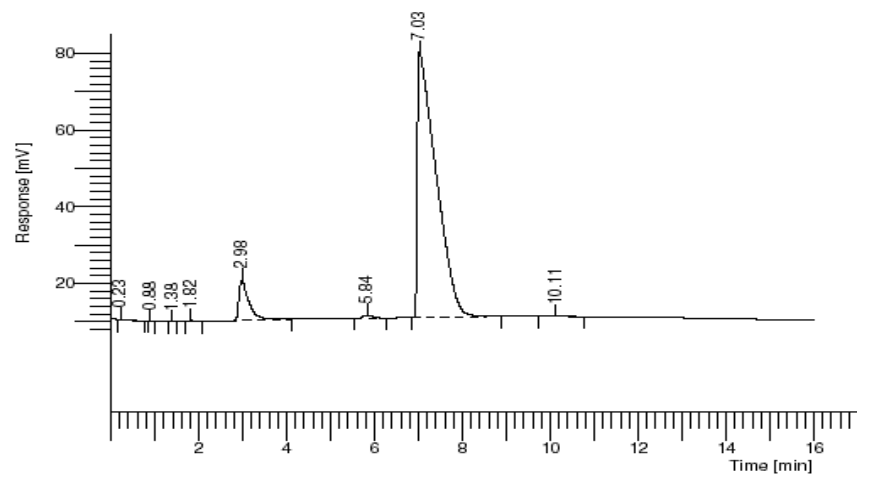

c. KZ B

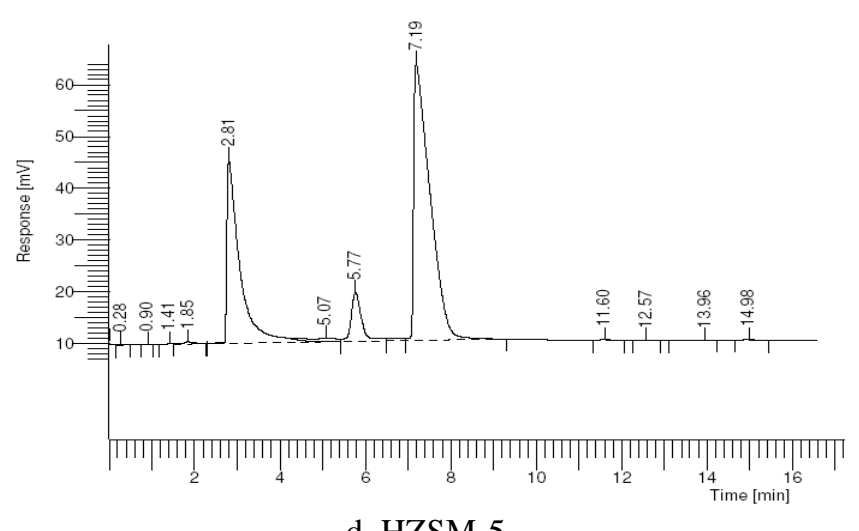

Figure 6. Khromatograph of liquid product ethanol dehydration

This is because KZ A catalyst has the largest surface area, therefore the possibility of reaction is larger than the use of the other catalyst. In addition, Yield value of diethyl ether is smaller than dehydration process with alumina catalyst. Yield of $\mathrm{KZ} \mathrm{B}$ is smaller than $\mathrm{KZ}$ A since the ration of $\mathrm{Si} / \mathrm{Al}$ for $\mathrm{KZ}$ $\mathrm{B}>\mathrm{KZ}$ A and surface area of KZ B is smaller than KZ A. Yield of diethyl ether for production process with HZSM-5 catalyst is 0 since there is no diethyl ether produced in the product.

Table 2 shows that the natural zeolite weight and chloride acid volume ratio affect to ethanol conversion. The higher reactant value the higher ethanol conversion. However, the conversion decrease after reactant ration of 1:20. The largest ethanol conversion is produced with ratio of zeolite weight and HCL volume is 1:20. This result follows the trend of catalyst surface area, but does not follow the trend of Si/AL ratio. This phenomenon shows that surface area and $\mathrm{Si} / \mathrm{All}$ ratio has an effect to ethanol dehydration process. Therefore, these two parameters need to be investigated into more detail.

Table 2. The result of ethanol conversion and DEE

\begin{tabular}{lcc}
\hline Catalyst type & $\begin{array}{c}\text { Ethanol } \\
\text { conversion }(\%)\end{array}$ & Yield DEE $(\%)$ \\
\hline KZ A 10 & 4,68 & 1,78 \\
KZ B 15 & 5,34 & 0,14 \\
alumina & 11,59 & 2,41 \\
HZSM-5 & 56,44 & 0 \\
KZ A: $1 / 10$ & 15.27 & 2.98 \\
KZ A: $1 / 15$ & 34.66 & 0.21 \\
KZ A: $1 / 20$ & 39.28 & 0.85 \\
KZ A: $1 / 30$ & 6.78 & 1.35 \\
\hline
\end{tabular}

\section{CONCLUSIONS}

Result of this research can be concluded as follows; XRD analysis result of catalyst product showed that $\mathrm{KZ}$ A catalyst is $\mathrm{H}$-zeolite with silicalite type and $\mathrm{KZ} \mathrm{B}$ is $\mathrm{H}$-zeolite with modernite type. The highest Specific surface area and total pore volume is $184,52 \mathrm{~m}^{2} / \mathrm{gram}$ and $108,243 \times 10^{-3} \mathrm{cc} / \mathrm{gram}$ respectively at dealumination time 10 hours for KZ A catalyst. Production proess result of diethyl ether showed that alumina catalyst, KZ A and KZ B, can be used to produce diethyl ether. However, HZSM-5 could not be used to produce diethyl ether and only increase the amount of water and might produce ethylene. The largest yield of diethyl ether was produced alumina, KZ A and KZ B in decreasing order. The largest ethanol conversion of $56.44 \%$ was produced by using HZSM-5 catalyst. The higher value of natural zeolite and chloride acid solvent ratio the higher surface area and ethanol conversion. The highest ethanol was produced at reantant ration of 1:20.

\section{ACKNOWLEDGMENTS}

The author would like to convey the acknowledgement to Dr. Suminar for the XRD analysis assistance, also sincere thank to Dr. Ir. Melia Laniwati as chief of instrumentation laboratory of ITB Bandung for the BET analysis assistance. Special thank to Mr. Kalyawan from Polytechnic Malang for the gas chromatography assistance. The writer also acknowledge to $\mathrm{DP}_{2} \mathrm{M}$ DIKTI as the sponsor of this research. 


\section{REFERENCES}

[1]. Ullmann, 1987, "Encyclopedia of Industrial Chemistry", Vol. A.10, $5^{\text {th }}$ edition, VCH Verlagsgesellschaft, Weinhem Federal Republic of Germany.

[2]. Butt, J. B., H. Bliss, and C. A. Walker, 1962, "Rates of Reaction in a Recycling System Dehydration of Etanol and Diethyl Ether Over Alumina", AIChE-J, 8, 42-47.

[3]. De Boer, JH, RB Fahim, BGLinsen, WJ Vissere and WFNM deVlesschauwer, 1967, "Kinetics of the Dehydration of Alcohol on Alumina", Jounal of Catalysis, 7 pp163-17

[4]. Smith, J.M. 1981. "Chemical Engineering Kinetics". McGraw-Hill Book Co, Singapura

[5]. Takahara I, M Saito, M Inaba, and K Murata, 2005, "Dehydration of ethanol into ethylene over solid acid catalysts", Catalysis Letters, Vol 105, pp 249-252

[6]. Haber J., K. Pamin, L. Matachowski, B. Napruszewska, and J. Pol_towicz, 2002, "Potassium and Silver Salts of Tungstophosphoric Acid as Catalysts in Dehydration of Etanol and Hydration of Ethylene", Journal of Catalysis 207, 296-306

[7]. Zaki, T., (2005), "Catalytic dehydration of ethanol using transition metal oxide catalysts", Journal of Colloid and Interface Science 284, p; 606-613

[8]. Varisli, D, T Dogu, and G Dogu, 2007, "Ethylene and diethyl-ether production by dehydration reaction of ethanol over different heteropolyacid catalysts", Chem Eng Sci

[9]. Kick-Othmer, (1965), "Encyclopedia of Chemical Technology", Vol. 8, $3^{\text {rd }}$ edition, John Wiley and Sons, Inc., United States of Amerika

[10]. Fessenden, Ralp J. dan Joan S. Fessenden, (1997), "Kimia Organik”, jilid 1 edisi ketiga, terjemahan oleh : Aloysius H. P, Penerbit Erlangga, Jakarta

[11]. Latourrette, B dan C., Magnier (1990), Preparation of Zeolite of type ZSM-5, US Patent No. 4891199.

[12]. Widayat, Mustafa, A Roesyadi and HM Rachimoellah, (2008), "Pengaruh Konsentrasi $\mathrm{HCl}$ Dan Jenis Reaktan Dalam Pembuatan Katalis Zeolit Untuk Proses Dehidrasi Dari Zeolit Alam”, Prosiding Seminar Nasional Rekayasa Kimia dan Proses 2008 Semarang, 